\title{
National Elections and Political Apathy: A Comparative Study of Voter Turnout in the 2019 General Elections of Nigeria and South Africa
}

\author{
Kenneth Nweke, Ph.D \& \\ Department of Political Science, \\ Ignatius Ajuru University of Education, \\ Rumuolumeni, P.M.B. 5047, Port Harcourt. \\ Eunice Etido-Inyang \\ Department of Political Science, \\ Ignatius Ajuru University of Education, \\ Rumuolumeni, P.M.B. 5047, Port Harcourt.
}

\begin{abstract}
This research examines the impact of political apathy on electoral participation in Nigeria and South Africa in the 2019 general elections. The paper determined the causes of political apathy, its impact on the electoral process as well as its trend (voter turnout) in the general elections of 2019 in Nigeria and South. This research was borne out of the need to address the increasing rate of political apathy, especially voter turnout in both democratic nations. The research argued that the causes of political apathy, particularly poor voter turnout in the two countries are attributable to political marginalisation, corruption, lack of trust in the electoral process, political violence and militarisation of the electoral system. The research further found that there is no significant difference in the nature and trend of the political apathy (voter turnout) in both countries. The Rational Choice Theory (Downs, 1957) and the Democratic Deprivation Theory (Ebenezer, 2017) were used to theoretically justify the potentials of political apathy in undermining democratic participation. This study used descriptive research design to determine the impact of political apathy on the 2019 national elections in both countries. Trends and nature of political apathy, particularly voter turnout in the two countries were ascertained using secondary data and the analysis was based on content analysis in view of the historical trends and nature of the research. The research concluded that there is an obvious decline in political participation in both countries due to lack of trust in the electoral process, among others, which has largely undermined the interest of the electorate in the political systems of both countries. This research, therefore, recommends that political elite in both countries should be transparent, honest, responsible and responsive in order to encourage voter turnout in both countries at future national elections. A free, fair and credible electoral process, the study also recommended, would help rebuild citizens' confidence in both countries' electoral processes.
\end{abstract}

Keywords: Political apathy, Voter turnout, National elections, Nigeria, South Africa

\subsection{Introduction}

South Africa is a parliamentary representative republic with three tier system of government. These tiers are made up of the legislative arm which consists of the National Assembly lower house) and the National Council of Provinces (upper house). The Executive, who remains the president and head of government, is elected by the general assembly. The third tier is its 
judicial arm which is independent. Nigeria, on the hand, practises a presidential system of government with the same three tier-structure - the legislature, executive and judiciary.

Between 1994 and 1999 when the new wave of democracy started in South Africa and Nigeria, respectively, political observers noticed a steady decline in citizens' participation in the political and electoral processes in the two countries. When in South Africa, apartheid regime ended in 1994 with the election of a democratically elected President of Negroe extraction, Nelson Mandela. It was difficult, according to Morais (2019), to gauge the turnout of voters (measure political apathy), as millions of eligible black South Africans, were not made to register to cast their ballots. The percentage of voter turnout was difficult to determine in the 1994 national elections in South Africa. Nevertheless, there was increased enthusiasm for political participation.

At the dawn of the Fourth Republic in Nigeria in 1999, 58 million registered to vote in the general elections. However, only 30 million voted. This represented $52 \%$ of voter turnout in the election (Ebenezer, 2018). The 1999 elections in South Africa fared better with 18 million registered to vote and 16 million voted in the elections. This represented $89 \%$ of voter turnout. This was also similar to the increased political participation recorded in Nigeria in 2003, where 42 million of registered voters of 60 million, voted, representing $70 \%$ of voter turnout (Ebenezer, 2018; Morais, 2019). There was, however, a decline in voter participation in the electoral process in South Africa in the 2004 national elections, as 16 million of 21 million of registered voters, voted in the elections. This represented $77 \%$ voter turnout and decline of $12 \%$ turnout rate from the previous elections in 1999.

In the subfield of electoral democracy and political participation, political apathy represents lack of psychological involvement in public affairs, emotional detachment from civic engagements and obligations, abstention from political activity and general lack of passion in the electoral process (INEC \& FES, 2011; Ebenezer, 2018). The difficulty in measuring general political apathy in a political system and process, made political scientists, in most cases, to focus on the electoral process and citizens participation in elections, to measure the presence or absence of political apathy in a democratic system. This research shall address the comparative analysis of political apathy in national elections in Nigeria and South Africa, using the statistical tools to measure voter turnout in the 2019 national elections in both countries. This is because, an active political system with citizens' political engagements in political discourse, civic obligation and public policy inclusiveness without the requisite increase in voter participation in the electoral process especially in voting during national elections, such democratic and political system is still seen to have political apathy of the citizenry.

With these identified variables in mind, the objectives arising from the following research questions will guide this research endeavour:

1. What are the causes of political apathy in a political/democratic system?

2. How does political apathy impact on the electoral process in both Nigeria and South Africa?

3. Prior to 2019, what has been the trend of political apathy (voter turnout) in both Nigeria and South Africa?

4. What was the nature of political apathy (voter turnout) in the 2019 national elections in Nigeria and South Africa?

For organisational decorum and comprehensive analysis and inclusiveness of the research objectives knitted in these research questions, the following sub-fields will be utilised: 
conceptual clarifications, theoretical justifications, trend of political apathy (voter turnout) in Nigeria and South Africa (1994-2015), causes of political apathy in Nigeria and South Africa, nature of political apathy in Nigeria and South Africa in the 2019 national elections, discussions of findings and evaluation, and conclusion and recommendations.

\subsection{Conceptual Clarifications}

Political apathy is "the lack of psychological involvement in public affairs, emotional detachment from civic obligations and abstention from political activity" (INEC \& FES, 2011; p.15). It is part of the general decline in citizens' involvement in political activities of a particular country or nation (Fagunwa, 2015). Citizens of a country may be very active politically in public opinion aggregation, policy formulation, civic engagement with government and political leaders in the attendance and participation in political functions and activities (summits, seminars, rallies, debates, town hall meetings etc.), and yet refused to turn out to vote on the day of elections. This is why political apathy can be measured in the context of voter participation in the electoral process (voter turnout). The concepts of vote, election, voter, voter turnout and democracy within the sub-field of political apathy need comprehension for synergy of analysis.

Basically, a vote is simply the official choice citizens make during election. When candidates present themselves for public or political offices, citizens make choices by way of expressing approval or disapproval for or against a particular candidate who presents himself/herself, or is presented by a political party, for an election. A voter is the person legally and constitutionally empowered to exercise this very important civic duty, right or obligation. This right is exercised in an election. Election is the official act or process by which citizens of a democracy choose their representatives for public or political offices. When elected, citizens expect political accountability from their political representatives with the exercise of their mandates. When this is not the cause, according to Ebenezer (2017, p.143), "voter apathy ensues which results in low voter turnout" during elections.

Voter turnout is simply the percentage of eligible voters who cast their ballots in an election. Pintor and Sullivan (2010) argued that voter turnout is usually expressed as the percentage of voters who cast a vote (including those who cast blank and invalid votes) in an election. Geys (2006) insisted that it is the totality of a number of people who participate in voting in a given election, and it is usually given in percentages. The level of political participation through voter turnout, according to Ebenezer (2017), determines the respect or disrespect such government gets from the people. Fortunately and unfortunately, political apathy can only be measured adequately in a democracy. Dunn (2005)) defined democracy as "self government, a way of living together in political freedom which ennobled the characters and refined the sensibilities of an entire community, a society governing itself where citizens choose freely and immediately for themselves" p. 38. The requirement for democracy is people's consent. This consent is supposedly given through elections and voter turnout. Lack of voter turnout, or the existence of political apathy, is seen, in most cases, as lack of consent in the democratic or political process or system respectively.

A comprehensive understanding of the concept of political apathy requires an understanding of the intricacies of politics, governance and political inclusiveness in such political system. Politics in this context being the activities that relate directly or indirectly to influencing or redirecting the actions or inactions of government and the political class especially in power 
relations and policy directions, formulations and implementations. The unwillingness of the citizens (especially the electorate) to be fully and actively engage in the political process, results in political apathy. This could be due to disenchantments, indifference or contentment for or against the electoral or political system. Political apathy will be measured using the demography of political participation in elections in Nigeria and South Africa, especially with respect to the 2019 national elections in these countries. This is because, the mandate of representation in this two countries that practise representative democracy, presupposes proxy political participation by political representative obtained and democratically given during elections. Lack of political participation of most citizens in most democracies beyond casting of ballots during elections, is judged in the context of the empowerment and ennoblement of political representatives to actively participate in the process on their behalf. This is why it is important to know why there is political apathy in the polity from a theoretical perspective.

\subsection{Theoretical Justification}

The first major political theorist that critically examined the justification or otherwise of political apathy was Downs (1957). In his book, "Economic Theory of Democracy", published in 1957, Downs formulated the "Rational Choice Theory". The Rational Choice Theory is now a classical theory used in the analysis of political apathy (especially voter turnout) for more than six decades now. The emphasis is basically on the reasons for voting and non-voting in an election. Voters, according to this theory, vote in an election to maximize benefits (Geys, 2006). Voters, before a particular election, calculate the expected benefits of voting and abstaining. If the benefits of voting exceed the cost of voting, the voter may likely vote. Again, if a voter sees the likelihood of not being able to influence the outcome of a particular election, with the perception that his/her vote will not count, the voter may likely abstain from voting (Ebenezer, 2017).

In Nigeria, the cost of voting in an election may include the risk of being killed in coming out to vote through sporadic shooting by military personnel, political thugs, militants or bomb targets and general insecurity on election day (Ebenezer, 2017). Some of these elements are applicable in South Africa's elections as evident in recent unrest during elections. In both Nigeria and South Africa, the perception of corruption, lack of accountability and lack of impact of a political dispensation on the lives of the citizenry in the areas of infrastructural development, citizens' empowerment and sustainable development as benefits of voting in an election, could trigger political apathy. Downs' (1957) Rational Choice Theory therefore, emphasised on the profitability or unprofitability of voting that may result in political participation or political apathy in the political and electoral system.

However, there are several criticisms of this theory by political scholars. Dowding (2005) criticised it for lack of consistency in explaining voter turnout in the real world turnout rate (practicality). Kirchgassner (2003) criticised it for not explaining abstention due to alienation, and Matsusaka (1995) criticised it for not recognising the power of information in shaping voting pattern especially in the modern age of digital technology and social media interactions and interconnectivity. Despite these criticisms, in looking at political apathy in South Africa and Nigeria, the theoretical contributions of the rational choice theory cannot be over-emphasised. 
Ebenezer (2017), drawing from "the paradox of (not) voting" by Geys (2006), agrees with both the Rational Choice Theory (1957) and the criticism by Kirchgassner (2003). This was based on the premise that the absence or presence of voters, who vote in an election to maximize benefits, does not (in any way) obliterate the fact that some voters abstained from voting because they felt the inconsequentiality of their votes in deciding the outcome of an election. This is applicable to voters in Nigeria and South Africa. Ebenezer (2017) went further to justify the Rational Choice Theory (1957) and Political Alienation Theory of non-voting by Kirchgassner (2003), with the Theory of Democratic Deprivation (TDD) in order to explain the causes of political apathy in a democratic or political system.

Kirchgassner (2003) had argued that, lack of political accountability, inconsequentiality (powerlessness) of voters and total disconnect from political parties' proposed policies (alienation) could (most likely) trigger abstention of voting by a voter. Put differently, abstention in voting is due to alienation. This is quite true, but does not limit the fact that alienated voters are more likely to vote as argued by Downs' Rational Choice Theory. To connect these two perspectives within the some prism in the context of political apathy, especially voter turnout, the Democratic Deprivation Theory with two distinct connotations (negative and positive) was theorised. Democratic Deprivation Theory observed that, "when people are deprived of democratic dividends in a democratic dispensation due to lack of political accountability (corruption and sustainable development), they tend to react either negatively or positively to either establish a sense of dissatisfaction to such democratic system (regime) or aggressively work towards changing such democratic dispensation for the better". The deprivation can produce either positive or negative outcomes. The outcome is positive (Positive Democratic Deprivation) "when the existing democratic dispensation or governance structure does not provide the desired dividend of democracy, is not accountable, cannot protect lives and property, lacks the provisions of sustainable development and does not improve on the standard of living of the people; the people (voters) react positively by democratically turning out en mass to vote out such government in a free, fair and credible election". This, he attributed to Downs (1957) argument that the more alienated the voters are, the more likely they turn out to vote.

On the other hand, negative outcome (Negative Democratic Deprivation) "arises when the existing democratic dispensation or governance structure does not provide the needed democratic dividends, is not accountable, cannot protect lives and property of the people, does not guarantee sustainable development and lacks the ability to better the living standard of the people; the people (voters) react by not wanting to be part of the electoral and political process (political apathy), by not turning out to vote (voter turnout) possibly with the assumption that their votes will not count, and that they cannot change such government through the electoral process". He attributed this to Kirchgassner (2003) argument that the more alienated the voters are, the less likely they turn out to vote in an election. The theory of Negative Democratic Deprivation (NDD) is due to dissatisfaction, lack of trust in the credibility of the electoral process and a sense of distrust between the government and the governed which breeds political apathy. This is applicable in Nigeria and South Africa.

\subsection{Research Methodology}

The work adopts a descriptive research design. This method helps to systemically and critically investigate, using available tools of research analysis, the variables that connect the 2019 elections in Nigeria and South Africa with respect to political apathy. Historical investigation is 
also used to ascertain the trends of political apathy in both countries since 1999. Relevant literature (text books, journals, newspapers; articles, periodicals, magazines, cyberspace, internet etc.) were reviewed to obtain appropriate data for this research. Content analysis; an analysis of both the manifest and latent content of body of literature through classification, tabulation and evaluation of important variables to ascertain the causes and probable effects of a given phenomenon, was used in the analysis of data.

\subsection{Trends of Political Apathy in Nigeria and South Africa}

Political apathy (usually measured through voter turnout) is not a new political term in Nigeria and South Africa. Both countries have witnessed increased, then steady decline in electoral participation of citizens (voters) in electoral contest. In South Africa, Morais (2019) opined that, from the records supplied by South African Electoral Commission, there was $89 \%$ voter turnout rate in 1999 national elections. South Africa operates a parliamentary, representative system of government. Registered voters were over 18 million in 1999, while over 16 million voted. This was $89 \%$ of registered voters. Similarly, at the dawn of the Fourth Republic in Nigeria, Ebenezer (2018) reported that voter turnout was 52\% in the 1999 general elections in Nigeria. Over 58 million voters registered, while over 30 million voted in the elections.

In 2003, there was an increase of over $18 \%$ in Nigeria. Voter registration was about 60 million while 42 million voted, representing $70 \%$ of the registered voters. The 2004 national elections in South Africa had a $12 \%$ decline. Records from the Independent Electoral Commission of South Africa (IEC) indicated that 21 million voters were registered to vote in the election; while 16 million voted. This was about $77 \%$. In the case of Nigeria, there was a similar decline after it peaked in 2003. In 2007, voter's registration was 62 million, voter turnout was 36 million and the percentage of voter turnout was $58 \%$. This was $12 \%$ decline from 2003 . Voter turnout was 18 million in South Africa in 2009. Registered voters stood at 23 million and the percentage of voter turnout was 77\%. The 2011 general election in Nigeria had 53\% voter turnout rate. This was a 5\% decline in voter turnout from the previous general elections. Registered voters were 73 million, while those that voted in the elections were 39 million. There was, however, a 3\% decline in voter turnout rate in South Africa in 2014 national elections. Voter's registration was 25 million, while 19 million voted. This represented $74 \%$ of registered voters. In the 2015 general elections in Nigeria, with registered voters standing at 67 million, voter turnout was 29 million which represented $43 \%$, a decline of $10 \%$ from the previous elections.

Nigeria and South Africa had their national elections in 2019. In South Africa, with a population of 57 million, voter's registration of 27 million and voter turnout of 17 million; the percentage of voter turnout was just $63 \%$. This was $11 \%$ decline from the 2014 national elections. Similarly, with a population estimated to be around 200 million, a voter registration of about 82 million; voter turnout was just 29 million representing 35\% of registered voters. This, according to the International Centre for Investigative Reporting (ICIR), was second to the lowest voter turnout rate in Africa as reported by the International Institute for Democracy and Electoral Assistance (I-IDEA).

From the report, the lowest voter turnout rate in Africa was the 1996 presidential election in Zimbabwe with just 32\%. The 2019 general elections in Nigeria with $35 \%$ was the second lowest in Africa. Others were Cape Verde, 36\%; Egypt, 41\%; Mali, 43\%; Democratic Republic of 
Congo, 45\%; Sao Tome and Principe, 46\%; Sudan, 46\%; Mozambique, 49\%; Algeria, 49\%; Cote d'Ivoire 53\%. The highest voter turnout rates were recorded in Rwanda, 98\%; Equatorial Guinea, 93\%; Angola, 90\%; Seychelles, 90\%; Guinea Bissau, 89\%; Zimbabwe, 87\%; Sierra Leone, 84\%; Kenya, 80\%; Liberia, 75\% and Burundi, 73\% all in Africa.

Figure 2:

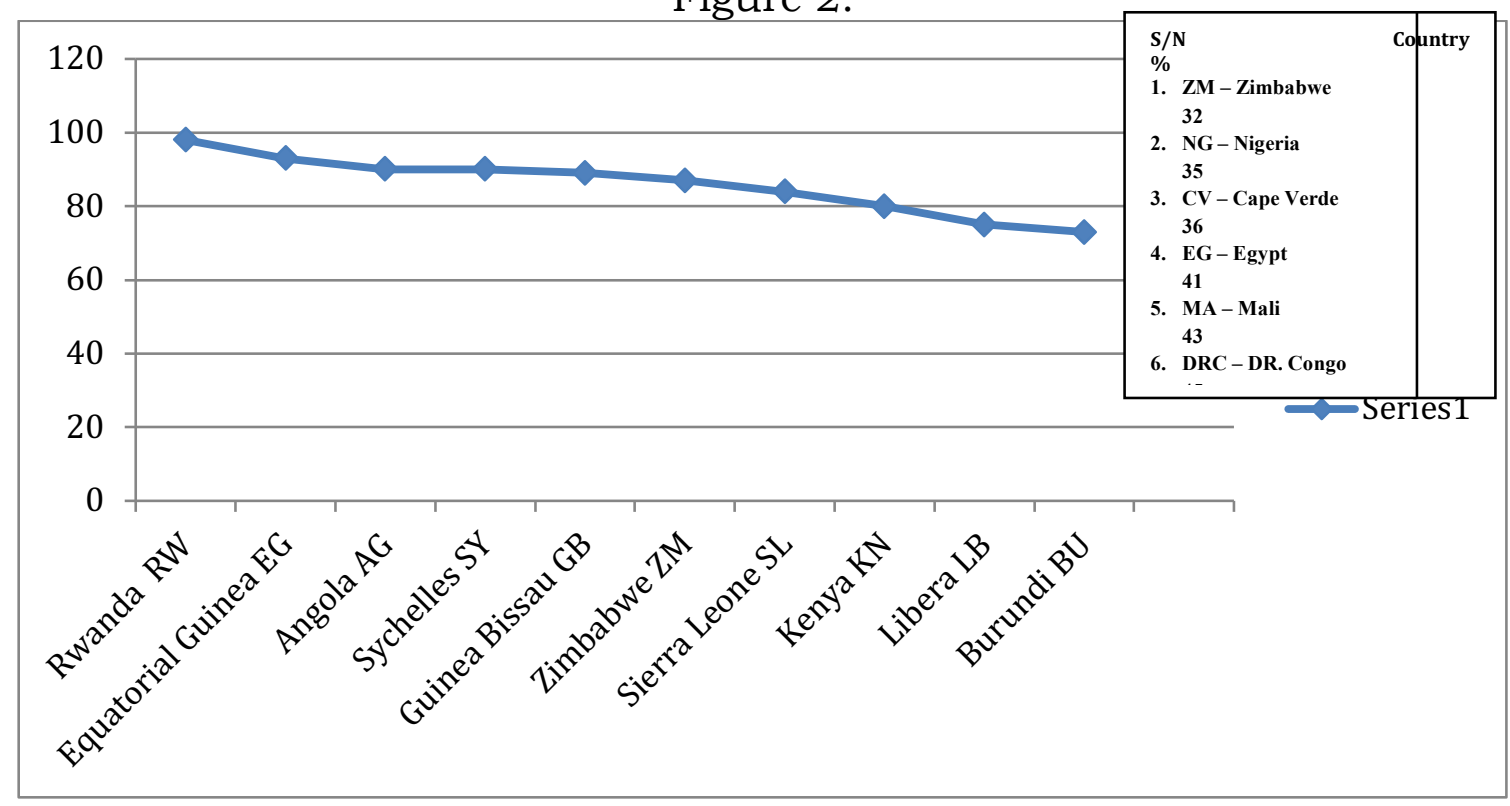

Comparative study of lowest voter turnout rates in Africa

Source: Researchers' Field Work, 2019

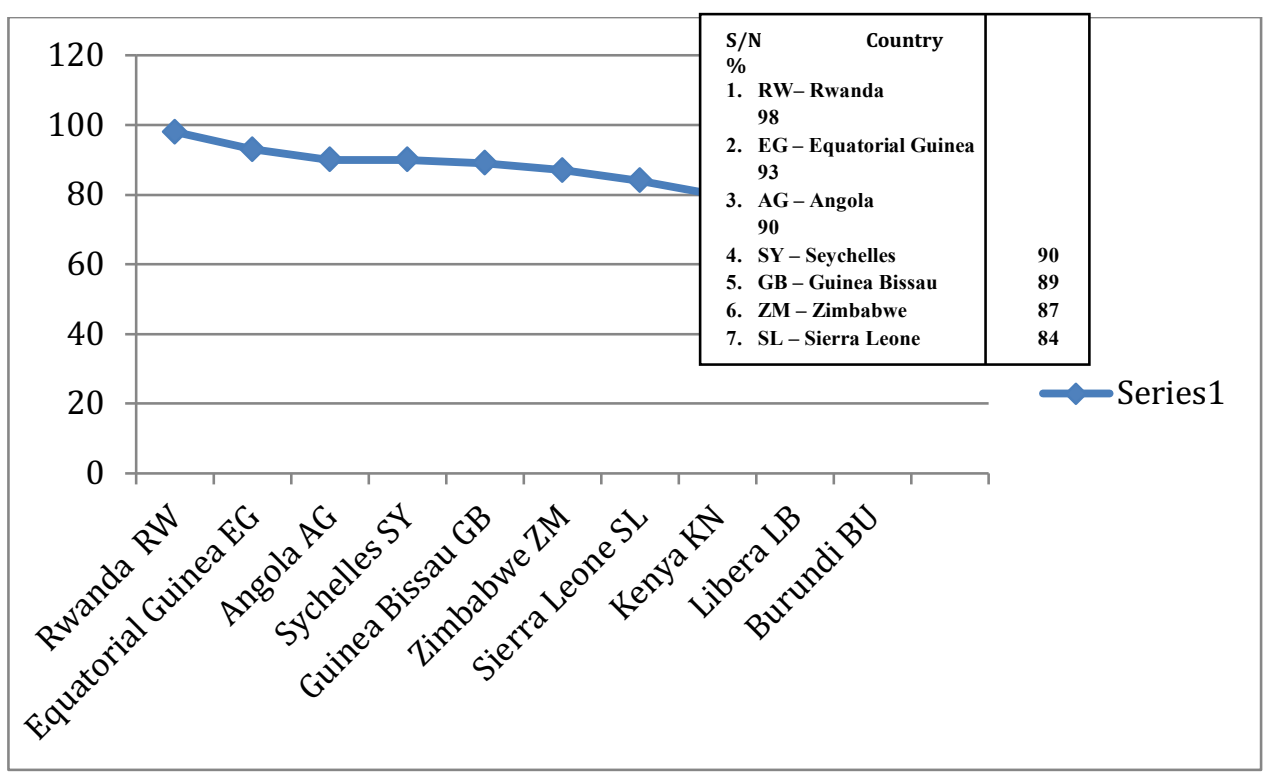

Graphic presentation of highest voter turnout rates in Africa. Rwanda has the highest rate.

\section{Source: Researchers' Field Survey, 2019}

\subsection{Causes of Political Apathy in Nigeria and South Africa}

Globally, political science scholars have identified lack of mobilisation, weather condition on the day of the election, lack of preference on the participating candidates, timing, ethnic affiliation, political party loyalty, political marginalisation, lack of civic engagement, accountability and motivation etc (Fowler, 2003; Morrow, 2015; Fagunwa, 2015) as some of the causes of political apathy. In Nigeria, political apathy arose due to failed promises of political leaders, corruption, violence, thuggery, lack of mobilisation in the electoral system, 
lack of credible leaders, ignorance, political deception, powerlessness of votes etc (Agagbe, 2015); INEC \& FES, 2011 as is the case in South Africa.

The Executive Director, Youth Initiative for Growth and Advancement (YIAGA), Sam Itodo, insisted that lack of democratic dividends to the people leads to political apathy. This, as he observed was because, "there is an affinity between democratic development and fulfillment of campaign promises" (Ojetunde, 2019). Morais (2019) reported that rain, cold weather, opaque government system and corruption caused political apathy in South Africa. A research conducted by Independent National Electoral Commission (INEC) and Fredrich-Ebert-Stiftung (FES), a research institute based in Germany observed that voters in Nigeria identified politicians, government and the electoral body (INEC) as responsible for political apathy (Ebenezer, 2018).

\subsection{Nature of Political Apathy in Nigeria and South Africa's 2019 National Elections}

Nigeria and South Africa witnessed low voter turnout in 2019 national elections. In South Africa, it was $63 \%$. This was $26 \%$ decline from the $89 \%$ voter turnout rate in 1999 . Since political participation in the electoral process especially elections, is the major yardstick in the measurement of political apathy in a democratic system, the $63 \%$ voter turnout rate in South Africa in 2019 was 14\%, 14\%, and 11\% decline in the 2004, 2009 and 2014 national elections, respectively. There is a steady decline in political participation in South Africa in the past 25 years. The 2019 elections recorded the lowest voter turnout rate since the end of apartheid, and the return of non-racial participating democracy in South Africa.

Similarly, at the dawn of the Fourth Republic in Nigeria, the uneasiness of the military and the citizen's lack of trust in the process led to an average political participation as was evident in the recorded voter turnout rate. It was $52 \%$ in 1999 . However, with high expectations and patriotic commitment to consolidating democracy, voter turnout in 2003 was recorded at $70 \%$. This showed increased political participation. Unfortunately, political violence, corruption, mistrust in the credibility of the electoral process and over militarisation of both the democratic and the electoral process in Nigeria led to a steady decline. Unlike South Africa that conducts national elections after every five (5) years, Nigeria had hers in every four (4) year. These elections have been used as yardstick in the measurement of political participation, and by extension, political apathy in these countries.

Nigeria's political participation (voter turnout) declined from $70 \%$ to $58 \%$, then to $53 \%, 43 \%$ and 35\% in 2003, 2007, 2011, 2015 and 2019 respectively. The 2019 general elections showed a decline of $17 \%$ from 1999, and 35\% from 2003 general elections. This is problematic and unhealthy for democratic consolidation and trust in the participatory processes in Nigeria's leadership recruitment system. Lack of political participation by citizens in a democratic system, delegitimized the political system and its leaders.

In 2019, with a population of 57 million, South Africa had a voter registration of 27 million. An African Check (2019) online report, noted that 9 million eligible voters in South Africa were not registered for the 2019 national elections. Therefore, while eligible voters were estimated to be about 36 million, 27 million registered, representing $75 \%$ of the eligible voters. However, 17 million voters participated which was $63 \%$ of registered voters. It should also be noted that the South African Independent Electoral Commission (IEC) reported that $63 \%$ of South Africa were eligible to register and vote in the 2019 national elections. 
The eligibility indicator in Nigeria was pegged at $60 \%$ according to the Independent National Electoral Commission (INEC). With an estimated population of 200 million, eligible voters in the 2019 general election was estimated to be about 120 million. Those that registered were 82 million, representing 68\% of eligible voters. Unfortunately, only 29 million voted, representing 35\% of registered voters in the 2019 general elections according to INEC. This was 35\% decline in political participation from 2003 general election when it peaked at $70 \%$ in Nigeria.

Furthermore, as indicated in the figure below, Nigeria's population is higher than that of South Africa. In fact, it is 140 million higher, and approximately four (4) times the population of South Africa. The eligible voters in Nigeria are approximately four (4) times higher than South Africa. Again, the registered voters in Nigeria are three (3) times higher than South Africa. Ironically, while $75 \%$ of eligible voters registered in South Africa and $63 \%$ of registered voters voted; only $68 \%$ of eligible voters registered, and $35 \%$ of registered voters voted in the 2019 general elections in Nigeria.

\section{Figure 4}

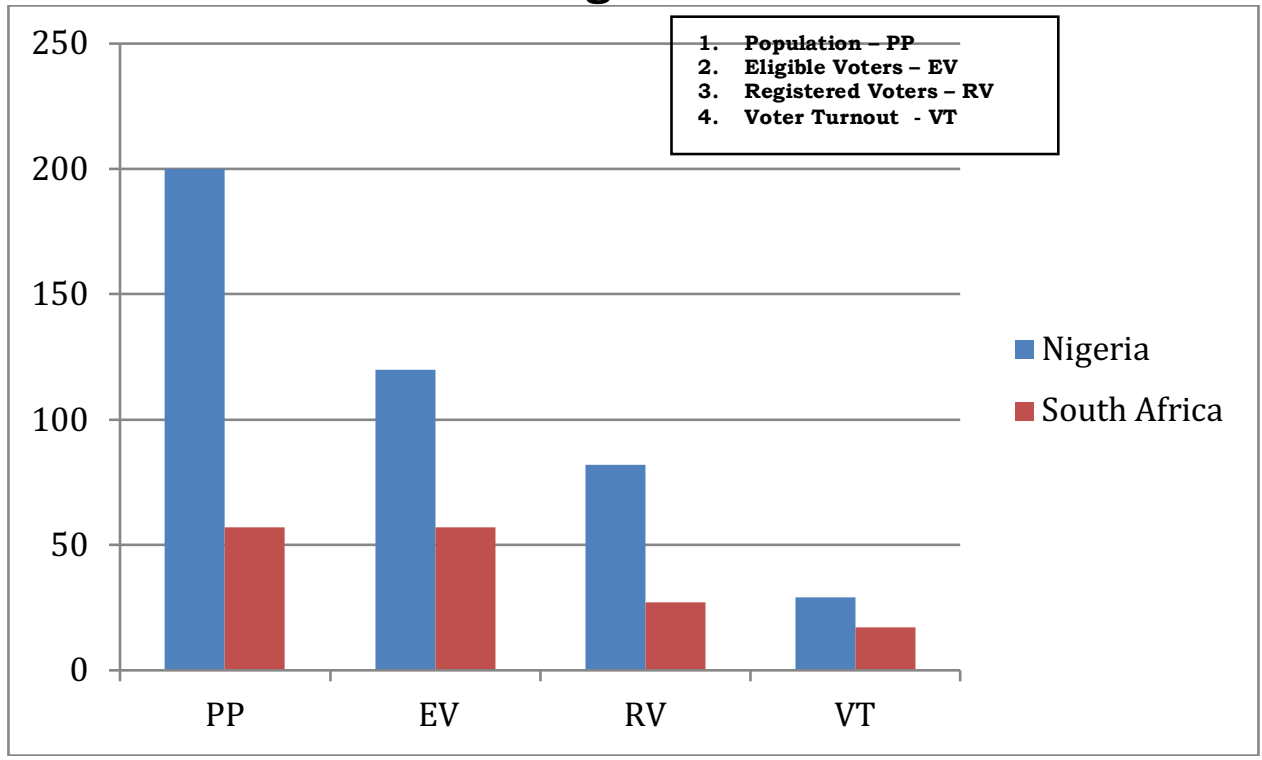

Comparative Presentations of Electoral Variables in Nigeria and South Africa in 2019 National Elections.

Source: Researchers' Field Survey, 2019

\subsection{Discussion of Findings and Evaluation}

At the beginning of the present dispensation in Nigeria (1999) and South Africa (1994), there were increase in voter turnout. In South Africa, everybody (especially blacks) from 18 years and above was allowed to vote without any official registration in 1994. With a documented voter's register in 1999 of 18,172,751 eligible voters registered to vote. Out of these, $16,173,754$ voted in the 1999 national elections. This was $89 \%$. In the case of Nigeria, it was $52 \%$ in 1999. Over 58 million registered and 30 million voted.

In 2003, Nigeria electorate felt the need to accord legitimacy to the democratic process after the initial distrust of the military's sincerity in handing over to a democratically elected civilian administration. 60 million Nigeria registered to vote, and 42 million voted in the elections. Voter participation in the election was $70 \%$ the highest in the unbroken 20 years of democracy in Nigeria. The 2004 election in South Africa witnessed a 12\% decline in voter's participation, was 16 million; while voter registration was 21 million. The decline in voter participation in 
2004 in South Africa after 10 years of democracy was based on gradual loss of interests in the democratic process according to Morais (2019).

The 2007 elections in Nigeria had a decline of $12 \%$ turnout rate. This was the genesis of the gradual apathy in the political and democratic processes in Nigeria. Available record from the Independent National Electoral Commission (INEC) showed that 36 million of 62 million registered voters participated in the elections in 2007. The percentage of voter turnout in 2007 was 58\%. This was attributed to lack of voter awareness, corruption and obsolete voting technology in Nigeria. There was also no improvement in political participation in the electoral process in 2009 in South Africa. Just a little above $77 \%$ of 23 million registered voters participated in the election. This showed that about 18 million electorate voted in the elections.

Voter participation in 2011 general elections in Nigeria was also in decline. Just about 39 million voters cast their ballots (voted). However, 73 million registered to vote. This was 53\% voter turnout rate, a 5\% decline from 2007. There was a similar scenario in South Africa with $3 \%$ decline in 2009. Percentage of voter turnout was 74\%. 25 million people had registered to vote while 19 million voted. Political participation in the 2015 general elections in Nigeria declined to $10 \% .67$ million people had registered to vote, but only 29 million voted. This was just about 43\%. Political apathy in Nigeria has been attributed to ignorance and deliberate deception by politicians (Falade, 2014). Ethnicity and religion had earlier been attributed to political apathy; voter participation depending on ethno-religious background of candidates presented by political parties (INEC \& FES, 2011). Political corruption and political violence notwithstanding, lack of political accountability and lack of impact of democracy on the citizenry are factors responsible for political apathy in Nigeria and South Africa.

As clearly shown in the 2019 elections in the Nigeria and South Africa, voters did not feel any sense of democratic fulfillment for 20 years and 25 years of uninterrupted democracy, respectively. Both countries had the worst decline in political participation in 2019. In Nigeria, it was 35\% voter's turnout rate. This was 8\% decline from 2015 and 35\% decline from 2003 when it peaked at 70\%. 82 million voters registered to vote while a paltry 29 million voted. In South Africa, 27 million people registered to vote in the 2019 national elections. Out of this, 17 million voted across the 22,925 voting districts, representing $63 \%$ voter turnout rate. This was $11 \%$ decline from the previous election in 2014, and 26\% decline when it peaked in 1999. These are worrisome signals to democratic consolidating in both countries.

From the above findings, one is pressured to logically assert that, while democracy is consolidating in the two countries judging from the number of years it has been practised; democratic dividends seem elusive. This dissatisfaction has created political apathy in electoral participation, public opinion aggregation, political debates, and town hall meetings and even in legislative public discourse on law making bills that require public scrutiny. This Negative Democratic Deprivation (NDD) meted out against the citizens by the political elite in the two countries should be addressed to enhance political participation and accord legitimacy to political authorities.

\subsection{Conclusion and Recommendations}

There is an obvious decline in political participation in Nigeria and South Africa as evident in the 2019 national elections in both countries. The decline had gone to 35\% (Nigeria) and 26\% (South Africa) in 2019 from 11\% and 8\% respectively. Political elite should also ensure that democracy and representation are people centered. There should be a beneficial synergy between elected representatives in government and the electorate whose mandate they represent. 
Accordingly, the following recommendations are put forward to ensure increase in political participation in Nigeria and South Africa especially electoral participation.

1. The electoral bodies in Nigeria and South Africa should be empowered to be independent in order to conduct free, fair and credible elections. This would arouse the patriotic zeal of citizens to perform civic duties of voting as a way of choosing political representatives in a democracy.

2. Political elite in government should exercise the citizens' mandate with transparency, honesty and responsibility. The dividends of democracy should be visible in the areas of infrastructural development, poverty alleviation, employment generation, literacy enablement and overall improvement in the people's standard of living.

3. The political and electoral system should be less violent and less militarised in both countries. The exercise of political rights should be democratic, free, and fair, without molestation and intimidation. Political apathy will be reduced when the electorate feels safe, free and comfortable in exercising their rights to vote or participate in the electoral or political processes.

4. Political apathy is borne out of perceived disregard for electorate's values in the polity. The level of political alienation and injustice in the polity especially in the processes of policy formulation and implementation has made political participation especially voting unattractive. There should be inclusivity on all fronts, a synchronisation of ideas between the government and the governed whether as candidates or supporters should be accommodated in the democratic process. Ethnicity, religion and political affiliation should not always decide who gets what, when and how in the polity.

5. There should improvement in the use of technology in the conduct of elections in both countries to enhance political participation. Electronic voting, use of ATM machines and POS devices configured with voter's card will enhance the credibility of the electoral process. Government and the electoral body should develop a technological system to enhance electoral credibility. Political apathy will be a thing of the past if voters are valued, respected and appreciated at all times. Sovereignty of the political system should be truly restored back to the people to curb political apathy in the democratic systems of Nigeria and South Africa.

\section{References}

African Check. (2019, February 15). Yes, more than 9 million eligible voters aren't registered for South African's 2019 elections. Retrieved May 25, 2019, from www.africacheck.org.

Agagbe, M. (2015). Voter Apathy and Voter Turnout in the 2015 General Elections: The Benue Experience. (Online Version). Retrieved May 25, 2019.

Downs, A. (1957). An economic theory of democracy. New York: Harper and Row.

Ebenezer, L. (2018). Political accountability and voter turnout in Nigeria's elections (1999-2015). Port Harcourt: University of Port Harcourt Doctoral Thesis.

Ebenezer, L. (2017). Trend analysis of voter turnout in Nigeria's elections (1999-2016), African Social and Educational Journal (Nigeria Edition), 6(2), 198-209.

Ebenezer, L. (2017). Political accountability and voter turnout in Nigeria's elections (1999-2016). Quarterly Journal of Contemporary Research, 5(2), 135-146.

Fagunwa, T. (2015). Voter apathy and Nigeria's electioneering process: a synopsis on 2015 general electrons. Retrieved May 25, 2019.

Falade, D. (2014). Political participation in Nigeria's democracy: a study of some selected Local Government Areas in Ondo State, Nigeria. Global Journal of Humanity/Social Science, 14(8), 16-22.

Fowler, G. (2013). Five studies on the causes and consequence of voter turnout. Harvard: Harvard Doctoral Dissertation.

Geys, B. (2006). National theory of voter turnout: a review. Political Study Review, 4, 16-35.

INEC \& FES. (2011). Voter apathy and the 2011 elections in Nigeria: a research report. Abuja: INEC \& FES Publication. 
INEC. (2019). 2019 Presidential Elections' summary results. Abuja. Retrieved May 25, 2019 from www.inec.org.

INEC. (2019). 2019 National and Provincial Elections; Electoral Commission of South Africa. Retrieved May 25, 2019, from www.elections.org.za>IEConline>.

Kirchgassner, G. (2003). Abstention because indifference and alienation and its consequences for party competition: a simple psychological model. University of Gallen: Economics Discussion paper 12.

Morais, S. (2019, May 9). Voter turnout trending down could be lowest in 25 years: news24. Retrieved May 25, 2019, from www.new24.com

Morrow, S. (2015). Causes of low voter turnout of the Hispanic population in South-West Texas. Texas: Walden University Doctoral Dissertation.

Ojetunde, D. (2019). Nigeria has the lowest rate of voter turnout in Africa. International Centre for Investigative Reporting (ICIR). Retrieved May 25, 2019, from www.icirnigeria.org

Pintor, R., Gratschew, M. \& Sullivan, K. (2010). Voter turnout rate from a comparative perspective in voter turnout. A Global Report, 75-116. 